Dokuz Eylül Üniversitesi-Mühendislik Fakültesi

Fen ve Mühendislik Dergisi

Cilt 19, Sayı 56, Mayıs 2017
Dokuz Eylul University-Faculty of Engineering Journal of Science and Engineering Volume 19, Issue 56, May 2017

DOI: $10.21205 /$ deufmd. 2017195656

\title{
Arttırılmış Gerçeklikte İşaretçi Tabanlı Takip Sistemleri Üzerine Bir Literatür Çalışması ve Tasarlanan Çok Katmanlı İşaretçi Modeli
}

\author{
Muhammet Fatih AKBAŞ ${ }^{* 1}$, Cengiz GÜNGÖR ${ }^{2}$
}

1İzmir Kâtip Çelebi Üniversitesi, Bilgi İşlem Daire Başkanlığı, 35620, İzmir

2Ege Üniversitesi, Uluslararası Bilgisayar Enstitüsü, 35100, İzmir

(Alınıș / Received: 15.04.2016, Kabul / Accepted: 23.02.2017, Online Yayınlanma / Published Online: 02.05.2017)

\begin{abstract}
Anahtar Kelimeler Özet: Arttırılmış gerçeklik, bilgisayarlı görü teknikleri Arttırılmıș Gerçeklik, Sanal Gerçeklik, Bilgisayar Grafikleri, Bilgisayarlı Görü, İşaretçi Tabanlı Takip Sistemleri, Çok Katmanlı İşaretçi Modeli kullanılarak, bilgisayar ortamında oluşturulan sanal içeriklerin, gerçek dünya üzerinde gerçek zamanlı olarak görüntülenebilmesine olanak sağlayan bir teknolojidir. Takip yöntemleri arttırılmış gerçeklik uygulamalarında önemli bir rol oynamaktadır. Bu çalışma kapsamında, arttırılmış gerçeklikte ișaretçi tabanlı takip sistemleri üzerine bir literatür çalıșması yapılmakta ve tasarlanan çok katmanlı işaretçi modeli tanıtılmaktadır. Çok katmanlı işaretçi modeli, gerçek dünya üzerine düşürülen sanal içeriklerin detaylarının yakından görülmesini ve işaretçiden uzaklaşıldığında oluşan görüntü kaybının önüne geçilmesini sağlamaktadır. Her bir katmanda bulunan işaretçi için görüntülemenin yapılabildiği takip mesafelerine çalışmada yer verilmektedir. İç katman kısa mesafeler için, dış katman uzak mesafeler için başarılı sonuçlar vermektedir.
\end{abstract}

\section{A Survey on Marker-Based Tracking Systems in Augmented Reality and Design of Multi-Layer Marker Model}

\begin{tabular}{l}
\hline Keywords \\
Augmented \\
Reality, \\
Virtual Reality, \\
Computer \\
Graphics, \\
Computer Vision, \\
Marker-Based \\
Tracking Systems, \\
Multi-Layer \\
Marker Model
\end{tabular}

*Sorumlu yazar: mfatih.akbas@ikc.edu.tr

\begin{abstract}
Augmented reality is a technology which allows virtual contents generated by computer to be displayed on the real world in real time using computer vision techniques. Tracking methods play an important role in augmented reality applications. In this work, a survey on marker-based tracking systems in augmented reality is presented and a multi-layer marker model is proposed. Multi-layer marker model enables details of the virtual contents displayed on the real world to be seen closely and prevention of image loss occurring when moved away from the marker. Tracking distances are given for markers in each layer. Inner layer and outer layer give good results for short distances and long distances, respectively.
\end{abstract}


M.F. Akbaş vd. / Arttırılmış Gerçeklikte İşaretçi Tabanlı Takip Sistemleri Üzerine Bir Literatür Çalışması ve Tasarlanan Çok Katmanlı İșaretçi Modeli

\section{Giriş}

Arttırılmış gerçeklik, gerçek dünyadan alınan görüntülerle bilgisayar ortamında oluşturulan görüntülerin birbirleri ile gerçekçi bir şekilde karıştırılması, örtüştürülmesi sürecidir. Bilgisayar ortamında oluşturulan yazı, grafik, video, ses ve GPS gibi sanal içeriklerin gerçek dünya üzerinde gerçek zamanlı olarak görüntülenebilmesine olanak sağlayan arttırılmış gerçeklik teknolojisi (Şekil 1), gerçek dünyanın zenginleştirilmesini, daha faydalı ve işlevsel hale getirilmesini sağlamaktadır. Sanal ve gerçek nesnelerin aynı uzayda bulunduğu ve etkileşimin tamamıla gerçek dünya üzerinde gerçekleștiği bu teknoloji, insanların algılama gücünü arttırmakta ve bulunulan ortamı farklı bir pencereden görülmesini sağlamaktadır [1].

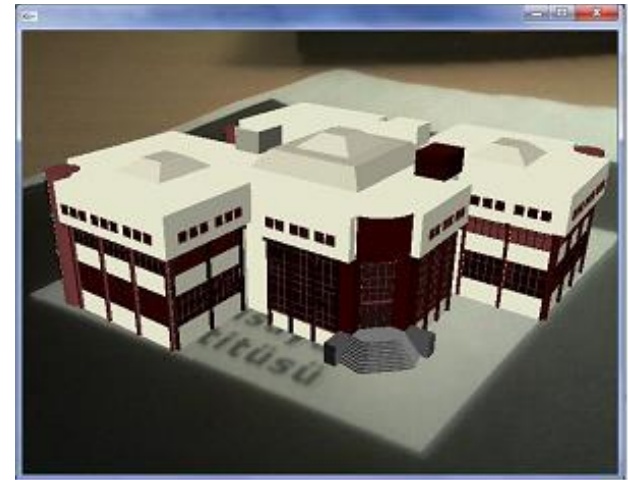

Şekil 1. Arttırılmış gerçeklik görüntüsü [1]

İdeal bir arttırılmış gerçeklik sisteminin üç temel özelliğe sahip olması gerekmektedir. Bunlar; gerçek ve sanal dünyayı birleştirmesi, etkileşimin gerçek zamanlı olması, gerçek ve sanal nesneleri birbirleriyle 3-boyutlu olarak çakıştırmasıdır [2].

Şekil 2'de arttırılmış gerçekliğin gerçek dünya ile sanal dünya arasındaki konumunu belirten gerçeklik-sanallık sürekliliği (reality-virtuality continuum) gösterilmektedir [3]. Soldan sağa doğru gidildikçe gerçeklik azalmakta ve sanallık artmaktadır. Sanal gerçeklikte ana fikir gerçek dünyanın yerini almak iken arttırılmış gerçeklikte ana fikir dijital içerikle gerçek dünyanın desteklenmesidir.



Güncel ve gelişmekte olan bu teknoloji, mühendislik ve mimarlık uygulamalarında, video oyunları ve film sektöründe, eğitim ve tıp alanında başta olmak üzere hemen her alanda uygulama alanı bulmaktadır. Konu ile ilgili en basit örnek futbol maçlarında sahaya yansıtılan bilgisayar görüntüleridir. Aynı şekilde, bu teknoloji ile bir aracın bakımı yapılmak istendiğinde araca ait bir parça hakkında bilginin arttırılmış gerçeklik gözlüğünün ekranına yansıtılarak sunulabilir. Ayrıca, müzelerde sergilenen eserler hakkında yazılı ve görsel ek bilgiler edinilebilir, yeni inşa edilen binaların üç boyutlu olarak gösterimi yapılabilir ve sanal trafik levhaları oluşturulabilir [4].

Tarihsel sürece bakıldığında 1901 yılında yazar Frank Baum, gerçek dünyaya veri aktaran ilk elektronik görüntüleyici cihazlardan bahsetmiş ve bunları karakter işaretçisi (character marker) olarak tanımlamıştır [5]. Sanal gerçeklik fikrinin öncülerinden biri kabul edilen görüntü yönetmeni Morton Heilig 1957 yılında Sensorama adı verilen bir simülatör olușturmuș ve 1962 yllında patentini almıștır. Bu simülatör sanal gerçeklik sisteminin olușturulmasındaki ilk çalışma olup kullanıcıya üç boyutlu olarak görebildiği, rüzgârı hissedebildiği, koku alabildiği ve ses duyabildiği bir ortam sunmaktadır [6]. 1968'de Ivan Sutherland, kullanıcının kafa hareketini takip ederek bakış açısını tahminleyen ilk başa takılabilir görüntüleyici (Head Mounted Display, HMD) cihazı geliștirmiștir. Bu cihaz, tavandan așağıya sarkan mekanik kollara sahip olup büyük 
ve ağır olmasından ötürü Demokles'in Kilicl (Sword of Democles) olarak adlandırılmıștır [7]. Fakat günümüzdeki giyilebilir cihazlara temel teșkil etmesi bakımından önemlidir. 1975'de Myron Krueger tarafından kullanıcılara görsel nesnelerle etkileșim imkânı sunan Videoplace adlı yapay gerçeklik sistemi geliștirilmiștir [8]. 1987'de Jaron Lanier tarafından sanal gerçeklik terimi kullanılmış ve kurmuş olduğu VPL Research adlı şirketinde sanal gerçeklik teçhizatları geliştirilmiştir. Sanal gerçeklik gözlüklerinin ve eldivenlerinin ticari olarak satışını yapan ilk şirket olmuştur [9]. Arttırılmış gerçeklik kavramı ise ilk olarak 1990'l y ylların bașında eski bir Boeing araștırmacısı olan Thomas Caudell tarafindan ileri sürülmüștür. Thomas Caudell ve David Mizell, başa takılabilir görüntüleyici teknolojilerinin kullanımı ile uçaklardaki kablo bağlantılarının düzgün bir şekilde yapılabilmesini sağlayan arttırılmış gerçeklik sistemi geliştirmişlerdir. $\mathrm{Bu}$ sistem ile çalışanların işlerindeki verimliliğin ve kalitenin yükseltilmesi amaçlanmıştır [10]. Louis Rosenberg, 1992 yllında ABD Hava Kuvvetleri Araştırma Laboratuvarı'nda Sanal Aparatlar (Virtual Fixtures) adı verilen arttırılmış gerçeklik sistemini geliştirmiștir. Sistemin insanların performansına sağladığı faydalar gösterilmiștir [11]. 1993 yllında ise Steve Feiner, Blair MacIntyre ve Doree Seligmann tarafindan KARMA (Knowledge-based Augmented Reality for Maintenance Assistance) adı verilen arttırılmış gerçeklik sistem prototipi hakkında yayın yapılmıştır [12]. Yine aynı yıl içinde Loral WDL adlı şirket, ABD Ordusu Simülasyon ve Eğitim Teknolojileri Merkezi ile arttırılmış gerçeklik donanımlı araçlar ve simülatörlerin bir arada bulunduğu bir sistem ortaya çıkarmışlardır [13]. 1994 yılında sanatçı Julie Martin, Avustralya Sanat Konseyi'nin vermiş olduğu destekle arttırılmış gerçeklik tiyatrosunu sahnelemiştir. Siber uzayda dans olarak adlandırılan bu gösteride dansçıların ve akrobatların bulundukları sahneye gerçek zamanlı olarak sanal nesneler yansıtılmıştır. Gösteride Silicon Graphics bilgisayarları ve Polhemus algilama sistemi kullanılmıștır [14]. Ronald Azuma, 1997 yılında arttırılmış gerçeklik konusu üzerine geniş kapsamlı bir araștırma çalıșması yayınlamıştır [2]. 1998'de Ramesh Raskar, Greg Welch ve Henry Fuchs, North Carolina Üniversitesi'nde sanal nesnelerin gerçek dünya üzerinde doğrudan görüntülenebilmesini sağlayan Mekânsal Arttırılmış Gerçeklik (Spatially Augmented Reality, SAR) paradigmasını tanıtmışlardır. Mekânsal arttırılmış gerçekliğin en büyük faydası başa takılabilir görüntüleyici cihazın kullanılmasına ihtiyaç duyulmamasıdır [15]. 1999'da Dr. Hirokazu Kato tarafından ARToolKit [16] adı verilen arttırılmış gerçeklik yazılım kütüphanesi geliştirilmiş ve SIGGRAPH konferansında sunumu yapılmıștır. Sonraki süreçte proje Washington Üniversitesi'nde bulunan HITLab, Canterbury Üniversitesi'nde bulunan HITLabNZ ve Seattle'da bulunan ARToolworks şirketi tarafindan desteklenmiștir. ARToolKit kütüphanesi ile geliștirilen uygulamalarda sanal nesnelerin gerçek dünya üzerinde görüntülenebilmesi için işaretçi (marker) kullanılmaktadır. 2000 'li yıllara geldiğimizde ise arttırılmış gerçeklik ağırlıklı olarak mobil platformlarda uygulama alanı bulmaya bașlamıștır. İlk örneklerden biri Bruce $\mathrm{H}$. Thomas tarafından geliştirilen ARQuake adlı mobil arttırılmıș gerçeklik oyunudur. ARQuake, popüler Quake oyununun arttırılmış gerçeklik versiyonudur [17].

Mobil cihazlar üzerindeki arttırılmış gerçeklik uygulamalarının sayısı her geçen gün artmakta ve konum tabanlı (location-based) servislerin kullanımı yaygınlașmaktadır. Günümüzde ise konum belirleyici (navigasyon) 
yazılımları artık mobil cihazlar üzerinde bir standart olarak gelmektedir. Dolayısıyla ek bir navigasyon cihazı kullanmak yerine akıllı telefonların bu özelliği kullanılmaktadır. 2008 yılında Avusturya'da kurulan Mobilizy firması tarafından konum tabanlı arttırılmıș gerçeklik uygulamalarının geliștirilmesini sağlayan Wikitude [18] adlı bir kütüphane geliştirilmiştir. Android, iOS ve BlackBerry10 mobil platformlarında uygulama geliștirmeyi destekleyen bu kütüphane ile kullanıcı akıllı telefonunun kamerasını, pusulasını, GPS bilgisini ve Wi-Fi bağlantısını kullanarak etrafında bulunan otelleri, restoranları ve mağazaları bulabilmektedir. Wikitude AR Seyahat Rehberi uygulaması, HTC tarafindan üretilen ilk Android tabanlı akıllı telefon olan G1 Android ile kullanıma sunulmuştur. $\mathrm{Bu}$ uygulama ile çevrede bulunan mekânlarla ilgili Wikipedia içeriği ekranda görüntülenebilmektedir [19]. Ayrıca, Wikitude uygulamasının en iyi arttırılmış gerçeklik tarayıcısı kategorisinde kazandığ $\breve{l}_{1}$ ödüller bulunmaktadır [20]. 2009 yllında ise Hollanda'da kurulan Sprxmobile firması, görü ve konum tabanlı mobil arttırılmış gerçeklik uygulamalarının geliștirilmesini sağlayan bir diğer kütüphaneyi geliştirmişler ve Layar [21] adı verilen uygulamayı bir mobil arttırılmıș gerçeklik tarayıcısı olarak tanıtmışlardır. Android ve iOS gibi mobil platformlarını destekleyen bu uygulama ile cihazın kamera, pusula, ivmeölçer, GPS bilgisi ve Wi-Fi bağlantısı kullanılarak çevrede bulunan satıllk evlerden, en yakında bulunan otobüs duraklarına varıncaya kadar çeşitli bilgilere erişilebilmektedir. Aynı yıl içinde Saqoosha, ARToolKit'i Adobe Flash ortamina uyarlayarak FLARToolKit [22] adlı ilk Adobe Flash tabanlı arttırılmış gerçeklik kütüphanesini geliştirmiştir. Böylece arttırılmış gerçekliğin web tarayıcılarına da desteği gelmiştir. Son yıllarda ise giyilebilir teknolojiler olarak akıllı gözlükler ve akıllı saatler popülerliğini arttırmaktadır. Vuzix [23], Meta [24] ve Google firmaları çeşitli arttırılmış gerçeklik gözlükleri üretmektedir. Google tarafından tasarlanan ve Google Glass [25] adı verilen arttırılmış gerçeklik gözlüğü, kamera, mikrofon, pusula, ivmeölçer ve GPS gibi birçok özelliği üzerinde barındıran mini bir bilgisayar olarak düşünülebilir. Gözlük, ses komutları ve kenarında bulunan dokunmatik yüzey ile kontrol edilebilmekte, Wi-Fi ve Bluetooth özelliği ile akıllı telefonla bağlantı sağlanabilmektedir. Gözlük ile internette arama yapabilmekte, üzerindeki kamera ile yüksek çözünürlüklü fotoğraf çekebilmekte, video kaydedebilmekte ve GPS ile konum belirlenerek istenilen adres bulunabilmektedir. 2015 yılında Microsoft, Windows 10 işletim sistemi ile çalışan HoloLens [26] adını verdiği arttırılmış gerçeklik gözlüğünü tanıtmıştır. Gözlük, yüksek çözünürlüklü holografik görüntüler olușturmakta ve bu görüntülerle etkileșime olanak sağlamaktadır.

Uzun yıllardır gündemde olan bir konu olmasına karşın özellikle son yıllarda mobil cihazların kullanımının yaygınlașması ve giyilebilir teknolojilerin revaçta olması arttırılmış gerçeklik kavramının daha fazla ön plana çıkmasını sağladı. Önümüzdeki yıllarda da arttırılmıș gerçekliğin özellikle akıllı telefonlar ve akıllı gözlükler üzerinde daha fazla karşımıza çıkması ve gündelik yaşamımızın bir parçası haline gelmesi beklenmektedir.

Bu çalışmanın ilk bölümünde, arttırılmış gerçeklik kavramı açıklanmakta ve tarihsel gelişim süreci anlatılmaktadır. İkinci bölümde, işaretçi tabanlı takip sistemleri üzerine yapılan çalışmalar incelenmekte, işaretçi tabanlı takip sistemlerinin genel yapısı ele alınmakta ve işaretçilerin önemine dikkat çekilmektedir. Üçüncü bölümde, 
M.F. Akbaş vd. / Arttırılmış Gerçeklikte İşaretçi Tabanlı Takip Sistemleri Üzerine Bir Literatür Çalışması ve Tasarlanan Çok Katmanlı İşaretçi Modeli

tasarlanan çok katmanlı işaretçi modeli detaylı olarak anlatılmakta ve bu işaretçi modelinin kullanımının sunduğu katkılardan bahsedilmektedir. Ayrica, her bir katmanda bulunan işaretçi için görüntülemenin yapılabildiği takip mesafeleri ölçülmekte ve gözlemlenen değerlere yer verilmektedir. Son bölümde ise yapılan çalıșma özetlenmektedir.

\section{2. İlgili Çalışmalar}

Literatürde arttırılmış gerçeklik konusu üzerine yapılmış birçok sayıda araştırma çalışması bulunmaktadır. Bu çalışmalarda arttırılmış gerçeklik teknolojileri, uygulamalar, karakteristikleri, tarihçesi ve gelecekteki eğilimleri geniş bir çerçevede ele alınmakta ve arttırılmış gerçeklik ortamlarının oluşturulmasında karşılaşılan zorluklar ve kısıtlamalar açıklanmaktadır [27-31].

Arttırılmış gerçeklik ortamlarını oluşturmak için birkaç temel unsur bulunmaktadir. $\mathrm{Bu}$ unsurlar, takip (tracking), görüntüleme (display), çakıştırma (registration) ve ayarlama (calibration) mekanizmalarıdır [32].

Takip mekanizması bir arttırılmış gerçeklik sisteminin en önemli bileşeni olup görüntülemenin yapılabilmesi için referans olarak alınan bir nesnenin tanımlanması ile 3-boyutlu konum ve yön bilgisinin hesaplanması sürecidir. Bilgisayar ortamında oluşturulmuş dijital içeriklerin gerçek nesnelerin üzerine düşürülmesi bu 3-boyutlu konum ve yön bilgisi ile mümkün olmaktadır. Görüntülemenin düzgün yapılabilmesi için bu bilginin doğru olarak hesaplanması gerekmektedir. Bu bilgide oluşabilecek yanlışlar görüntülemenin hatalı olmasına neden olmaktadır. İyi bir takip sistemi, gerçek ve sanal nesnelerin bir arada görünmelerine olanak sağlayarak, sanal nesneleri gerçek dünyanın tamamlayıcı bir unsuru olarak göstermektedir [33].

Bir takip sisteminin üç temel özelliğe sahip olması gerektiği belirtilmektedir. Bunlardan birincisi, konum ve yön bilgisindeki hatanın minimum seviyede olmasıdır. Özellikle konum bilgisindeki hatanın 1-2 mm'den fazla olmaması gerektiği aksi takdirde görüntülemede hataların olacağı ifade edilmektedir. İkincisi, takip sisteminin gecikme süresinin çok düşük olması gerektiğidir. Burada sözü edilen gecikme süresi, dijital içeriğin görüntülemenin yapıldığı aygıt üzerinde belirmesi sürecinde geçen zamandır. Bu sürenin de 2 ms'nin altında olması önerilmektedir. Üçüncüsü, bir takip sisteminin özellikle dış mekânlarda olmak üzere uzak mesafelerde çalışabilmesi gerektiğidir [34].

Arttırılmış gerçeklikte, sensör tabanlı takip yöntemi, görü tabanlı takip yöntemi ve hibrit takip yöntemi olmak üzere üç takip yöntemi bulunmaktadır. Sensör tabanlı takip yöntemi kendi içinde optik, manyetik, akustik ve durağan olmak üzere dörde ayrılmaktadır. Görü tabanlı takip yöntemi ise kendi içinde işaretçi tabanlı ve işaretçisiz tabanlı olmak üzere ikiye ayrılmaktadır. Hibrit takip yöntemi ise sensör tabanlı ve görü tabanlı takip yöntemlerinin bir arada kullanılmasıdır. Her bir takip yönteminin kendine özgü avantajları ve dezavantajları bulunmaktadır [35]. Başarılı bir arttırılmış gerçeklik uygulaması geliştirmek için en uygun takip yönteminin seçilmesi gerekmektedir. Bu bölümde, literatürdeki işaretçi tabanlı takip sistemleri üzerine yaplan çalışmalar anlatılmaktadır.

\section{1. İşaretçi tabanlı takip}

Takip yöntemleri, arttırılmış gerçeklik uygulamalarında önemli bir rol oynamaktadır. İşaretçi tabanlı takip (marker-based tracking) yöntemi, çakıştırma işlemini başarılı bir şekilde 
M.F. Akbaş vd. / Arttırılmış Gerçeklikte İşaretçi Tabanlı Takip Sistemleri Üzerine Bir Literatür Çalıșması ve Tasarlanan Çok Katmanlı İșaretçi Modeli

yapabilmesinin yanı sıra düşük maliyeti ve kolay kullanımı ile en çok tercih edilen yöntemlerden birisidir. İșaretçi tabanlı takip sistemlerinde ana fikir, takip amaciyla 'fiducial' adı verilen işaretçilerin kullanılmasıdır. Gerçek dünya üzerinde referans noktası olarak alınan işaretçiler, çevreye yerleștirilmiş ve kameralar tarafından algılanabilen desenlerden meydana gelmektedir. İşaretçilerin temel özellikleri sahip oldukları șekil ve içlerinde bulunan desendir. İşaretçiler yardımıyla koordinat sistemini oluşturan $\mathrm{x}, \mathrm{y}$ ve $\mathrm{z}$ eksenleri elde edilmektedir (Şekil 3). Böylece bilgisayara fiziksel dünyada bulunan işaretçinin konum bilgisini vermek mümkün olmaktadır [37].

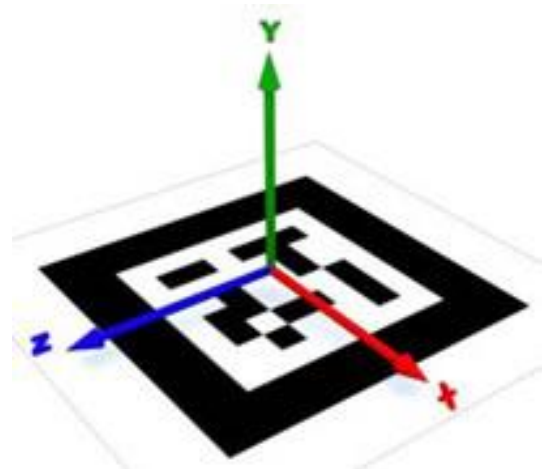

Şekil 3. İşaretçi ve eksenler [37]

Șekil 4'de ișaretçi tabanlı sistemlerin genel yapısı basitleștirilmiş bir formda gösterilmektedir [33]. İlk adımda canlı video akışından film kareleri gelmekte ve film karesi işlenmektedir. Görüntü işlendikten sonra işaretçinin aranması süreci başlar. Bulunan işaretçiler ile önceden tanımlanmış işaretçiler karşılaştırılır. Bir eșleșme bulunursa ișaretçilerin 3-boyutlu konum ve yön bilgisi hesaplanır ve bu bilgi kullanılarak sanal nesneler gerçek dünya üzerine düşürülür. Böylece gerçek ve sanal nesnelerin bir arada göründügü zenginleştirilmiş bir sahne ortaya çıkar.

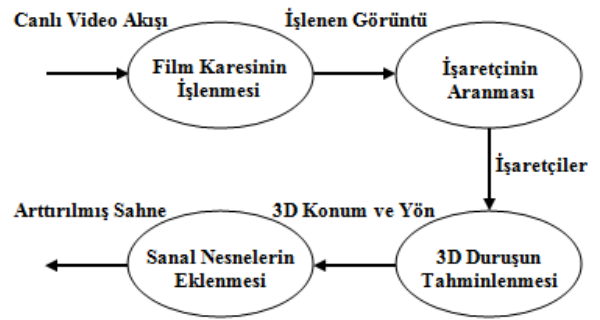

Șekil 4. İșaretçi tabanlı takip sistemlerinin genel yapısı [33]

Başarılı bir işaretçi tabanlı arttırılmış gerçeklik sistemin tasarlanmasında ișaretçinin șekli, büyüklüğü, rengi, deseni ve desenin nasıl tanımlanacağı önem teşkil etmektedir. 3-boyutlu konum ve yön bilgisinin başarılı bir şekilde hesaplanabilmesi için işaretçinin birbirinden uzak en az dört köșe noktasına sahip olması gerekmektedir. İşaretçinin kare şeklinde olması gerekmemekle birlikte ișlemsel açıdan basitlik sunması bir avantajdır. Siyahbeyaz kare işaretçiler, renkli işaretçilere göre daha güvenilir sonuçlar vermektedir. Renkli ișaretçiler tercih edildiğinde ise bir takım zorluklar yaşanabilmektedir. Özellikle, ışı ve yansıma gibi ortam koşulları göz önüne alındığında renklerin birbirlerinden ayırt edilememesi durumu ortaya çıkabilmektedir. Ayrıca işaretçilerin siyah geniş sınırlara sahip olması daha kolay tanımlanabilmelerini sağlamaktadır [38].

Geliştirilen arttırılmış gerçeklik uygulamasına göre işaretçiler farklı formatlarda tasarlanabilmektedir. Fakat işaretçilerin tasarlanması sürecinde yüksek güvenilirliğe sahip olmasına dikkat edilmelidir. Karışıklığa sebep olmamak için ortamda bulunan işaretçiler birbirinden yeterince ayrık durumda olmalıdır. Ayrica, ideal bir işaretçi tabanlı takip sistemi birbirinden farklı çok sayıda işaretçiden oluşan bir kütüphaneye sahip olmalıdır. İşaretçinin kısmi olarak kapatılması durumlarında, ışığın yetersiz olduğu ortamlarda, 
M.F. Akbaş vd. / Arttırılmış Gerçeklikte İşaretçi Tabanlı Takip Sistemleri Üzerine Bir Literatür Çalışması ve Tasarlanan Çok Katmanlı İşaretçi Modeli

görüntüde gürültünün ve bulanıklığın olduğu durumlarda işaretçilerin tespit edilebilmesi için görüntü işleme algoritması güçlü olmalıdır [39].

İşaretçi sistemleri şekillerine göre dairesel ve kare işaretçiler olmak üzere ikiye ayrılmaktadır. Dairesel işaretçilerde dairenin merkezinin sabit olduğundan 3boyutlu konum bilgisinin hesaplanmasında kameranın bakış yönünün bir etkisi yoktur. Literatürde, arttırılmış gerçeklik uygulamaları için eş merkezli iç içe geçmiş dairelerden oluşan bir dairesel işaretçi tabanlı sistem önerilmiștir (Şekil 5). Bu sistemde, en içteki daire ile her bir halkanın farklı renge sahip olduğu ișaretçi modeli tasarlanmıştır. Her bir işaretçi, halkaların sahip olduğu renkler tarafindan tanımlanmaktadır. Önerilen sistem, takip mesafesini arttırarak geniş alanda takibi mümkün kılmak için basit ve düşük maliyetli bir yol sunmaktadır. Ayrıca geniş ölçekli arttırılmış gerçeklik uygulamalarının gerçekleştirilebileceği belirtilmektedir [40].

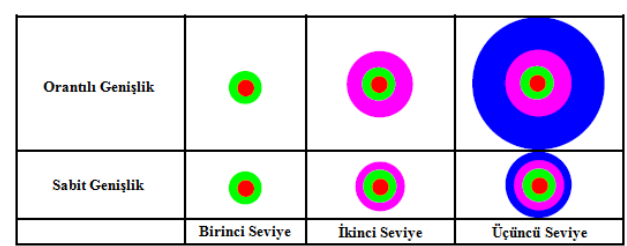

Şekil 5. Çok halkalı renkli dairesel işaretçi [40]

Başka bir çalışmada, Şekil 6'da gösterilen dairesel işaretçiler kullanılarak 2-boyutlu yeni bir barkod sistemi geliştirilmiştir. $\mathrm{Bu}$ sistem, ürünlerin tanımlanmasında yaygın olarak kullanılan veri matrisi kodlarına benzemektedir. Bir iç halka, bir diş halka ve iki veri halkasından oluşan dairesel işaretçiler siyah ve asimetrik beyaz bölgelere sahiptir. Sistem, birbirinden farklı binlerce işaretçi üretebilmekte ve geniş alanda takip için kullanılabilmektedir. Ayrıca, üretilen işaretçilerin tanımlanabilmesi için homomorfik görüntü işleme teknikleri kullanılmaktadır [41].



Şekil 6. Dairesel 2-boyutlu barkod işaretçi [41]

Diğer bir çalışmada, kamera duruş takibinin yapılabilmesi için dairesel işaretçi tabanlı bir yaklaşım sunulmaktadır. Tasarlanan işaretçi basit bir yapıya sahip olup içinde herhangi bir desen veya kod bulunmamaktadır. Kamera duruşunun hesaplanabilmesi için Şekil 7'deki etrafı beyaz şerit ile çevrili siyah bir daireden oluşan işaretçi ve işaretçinin tanımlanabilmesi için elips yerleştirme algoritması (ellipse fitting algorithm) kullanılmaktadır. $\mathrm{Bu}$ algoritma ile işaretçinin belli bir kısmı kapatılsa dahi işaretçi tanımlanabilmektedir. Bu işlem kapatılan kısımların yerine elipsler yerleștirilerek yapılmaktadır. Yapılan testlerde işaretçinin \%50'den fazlasının kapatılması durumunda dahi işaretçi başarıyla tespit edilebilmektedir [42].

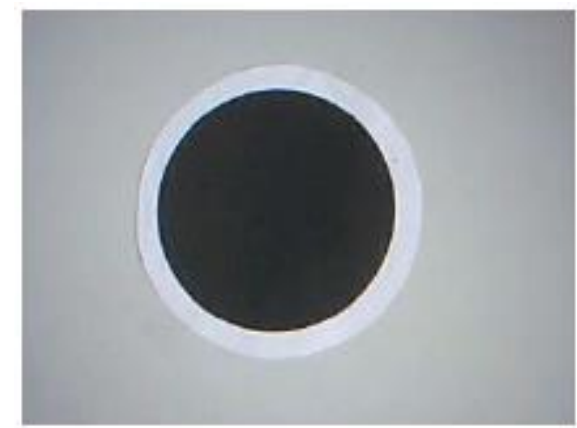

Şekil 7. Beyaz şeritli siyah dairesel işaretçi [42]

Kare işaretçiler, dört köşeye sahip olduğundan kamera duruşunun daha iyi hesaplanabilmesini sağlamaktadır. $\mathrm{Bu}$ yüzden, Şekil 8'deki işaretçiler ve benzerleri arttırılmış gerçeklik 
M.F. Akbaş vd. / Arttırılmış Gerçeklikte İşaretçi Tabanlı Takip Sistemleri Üzerine Bir Literatür Çalışması ve Tasarlanan Çok Katmanlı İşaretçi Modeli

uygulamalarında daha yaygin olarak kullanılmaktadır. Dr. Hirokazu Kato tarafından kare işaretçilerin ve bilgisayarlı görü algoritmalarının kullanıldığı ilk arttırılmış gerçeklik yazılım kütüphanesi olan ARToolKit geliștirilmiştir. Siyah sınırlara sahip, kare şeklinde olan ARToolKit işaretçileri içinde simetrik olmayan ve ince detaylar barındırmayan desenlerden oluşmaktadır [43].
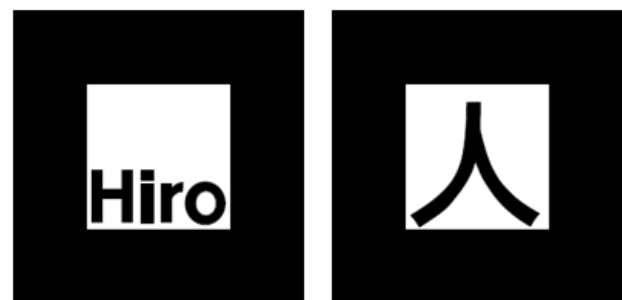

Şekil 8. Hiro ve Kanji işaretçileri [43]

Şekil 9'daki çoklu kare işaretçilerin kullanıldığı bir çalıșmada, video tabanlı bir arttırılmış gerçeklik konferans sistemi ve bu sistemde kullanılan bilgisayarlı görü teknikleri anlatılmaktadır. Önerilen bilgisayarlı görü teknikleri, işaretçilere yaklaşıldığında iyi sonuçlar vermektedir. İşaretçilerden uzaklaşıldığında ise konumlandırmanın doğruluğu azalmaktadır [44].

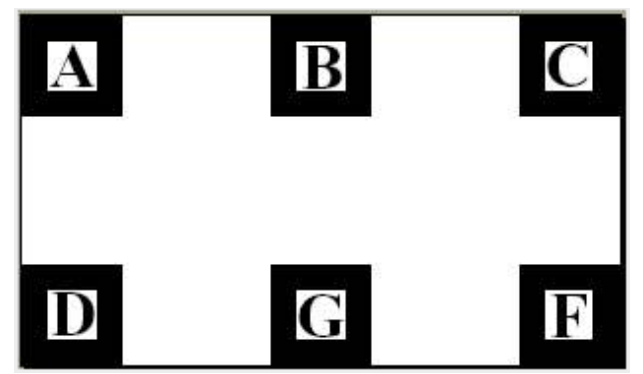

Şekil 9. Çoklu işaretçiler [45]

Arttırılmış gerçeklik uygulamaları için geliştirilen CyberCode, 2-boyutlu barkod teknolojisini kullanan görsel bir etiketleme sistemidir. Şekil 10'daki gibi 2-boyutlu desenler, her bir karenin siyah veya beyaz değerine sahip olduğu karelerden oluşmaktadır. Bilgi, bu 2boyutlu desenlerde kodlanmaktadır. Desenin düzeni etiketin ID numarasını belirlemektedir. CyberCode etiketleri, CMOS ya da CCD kameraları tarafindan tanımlanabilmektedir [46].


Şekil 10. CyberCode görsel etiketleri [46]

İşaretçilerin takibi için yapılan bir çalışmada makine öğrenmesi yöntemi önerilmektedir. Bu yöntemde ilk olarak ortamdan örnek işaretçi görüntüleri alınmaktadır. Sonrasında ise bir sınıflandırıcı eğitilmektedir. Her film karesinin her bir pikselini çevreleyen alt pencereler işaretçi olup olmadığına göre sinıflandırılmaktadır. Eğitilen örnekler 12x12'lik piksel görüntülerinden oluşmaktadır. Alt pencerelerin sinıflandırılması için bu eğitim seti kullanılmaktadır. Her bir film karesi için çok fazla sayıda sinıflandırma yapılacağından sınıflandırıcı hızlı olmalıdır. Sınıflandırıcı için iki adımlı bir yöntem kullanılmaktadır. Birinci adımda Bayes kuralı uygulanmaktadır. Bu adım, hızlı ve düșük yanlıș pozitif oranına sahiptir. İkinci adımda ise en yakın komşuluk (nearest neighbour) kuralı uygulanmaktadır. Birinci adımdan geçen alt pencereler ikinci adımda tekrar bir sınıflandırma işlemine tabi tutulur. Daha yavaş olan bu adımda, sınıflandırma işleminin yüksek oranda doğru yapılması sağlanır. $\mathrm{Bu}$ da yüksek hesaplama maliyeti gerektirir. Yapılan ölçümlerde, sistemin \%95 oranında bir performans gösterdiği belirtilmektedir [47].

İşaretçi sistemlerin performansını belirleyen bazı ölçütler bulunmaktadır. Bunlar; yanlış pozitif (false positive) oranı, yanlış negatif (false negative) 
M.F. Akbaş vd. / Arttırılmış Gerçeklikte İşaretçi Tabanlı Takip Sistemleri Üzerine Bir Literatür Çalışması ve Tasarlanan Çok Katmanlı İșaretçi Modeli

oranı, işaretçiler arası karışıklık oranı (inter-marker confusion rate) ve işaretçinin boyutudur. Ayrıca $1 s ̧ \mathrm{k}$ koșulları ve görüntüdeki titreșim de göz önünde bulundurulması gereken diğer performans ölçütleridir. Bilgisayarlı görü sistemleri üzerine akademik araștırma yapan Mark Fiala, ARToolKit'den esinlenerek ARTag adını verdiği (Şekil 11), dijital kodlama teorisine dayanan işaretçi tabanlı bir sistem önermektedir. Diğer ișaretçi sistemlerde kullanılan ikili eşiklenmiş görüntü (binary thresholded image) yerine kenar tabanlı (edge-based) işaretçi tanımlama yaklaşımı sunulmaktadır. Kenar tabanlı yaklaşım, farklı ıșı koșulları altında ve ișaretçinin bir kenarının veya köșesinin kapatılması durumunda dahi işaretçinin tanımlanabilmesini sağlamaktadır. Sistem üzerinde benzersiz ID numaralarına sahip 2002 adet işaretçi kodlanabilmektedir. Herhangi bir desen dosyasının yüklenmesi gerekmemektedir. ARTag, ARToolKit kütüphanesine kıyasla daha düşük yanlıș negatif oranına sahiptir. Ayrıca çok daha düşük yanlış pozitif hata oranına $(\% 0,0039)$ sahiptir. ARTag işaretçileri, kare bir sinıra sahip, $6 \times 6^{\prime} l \mathrm{lk}$ siyah ya da beyaz hücrelerden meydana gelen düzlemsel işaretçilerdir. Bu hücrelerde sayısal olarak 0 veya 1 temsil edilmektedir [48]. Stephen Cawood ve Mark Fiala'nın 'Augmented Reality: A Practical Guide' [36] adlı kitabında ARTag'in çalışma mantığı detaylı olarak anlatılmaktadır.

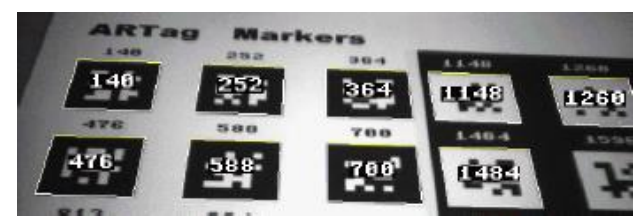

Şekil 11. ARTag işaretçileri [48]

Hücrelerden meydana gelen düzlemsel ișaretçilerin tasarlandığı bir bașka çalıșmada ișaretçilerin 3-boyutlu konum bilgisini yüksek bir doğruluk oranı ile tahminleyen bir işaretçi sistem önerilmektedir. Sistemde her bir ișaretçi koyu renk olarak siyah ve mavi, açlk renk olarak ise beyaz ve sarı renkli kare hücrelerden oluşmaktadır (Şekil 12). Renk bilgisi, birbirinden farklı 65000'den fazla işaretçinin kullanılabilmesini ve ișaretçilerin tanımlanabilirliğini zorlaștıran zayıf ıșık koșullarının tespit edilebilmesini sağlamaktadır. Renk bilginin kullanılmadı̆̆ı diğer ișaretçi sistemlerine göre daha hassas hesaplamalar yapabilen bir sistem olduğu belirtilmektedir [49].

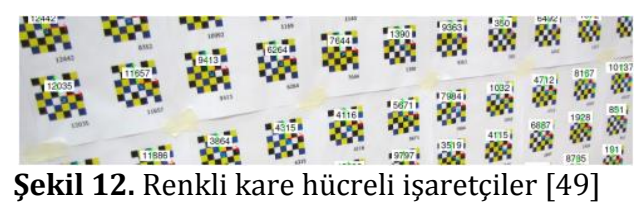

Şekil 13'de gösterilen ARForce adı verilen kare işaretçilerin kullanıldığı bir diğer arttırılmış gerçeklik sisteminde parmak ucu hareketlerini takip eden yeni bir yöntem önerilmektedir. Bilgisayarlı görü tekniği ile ișaretçinin 3-boyutlu konum, yön, ID bilgisi ve kullanıcı tarafından işaretçiye uygulanan kuvvet vektörlerinin dağılımı hesaplanmaktadır. $\mathrm{Bu}$ sayede, kullanıcı parmak ucu ile döndürme ve ittirme hareketlerini uygulayarak sanal nesnelerle doğal bir şekilde etkileşimde bulunmaktadır. ARForce sistemi kullanılarak geliștirilen Movie Player adlı uygulamada kullanıcı işaretçi üzerinde görüntülenen filmin zamanını kontrol edebilmektedir. Kullanıcı elini saat yönünde çevirdiğinde film de zaman olarak ileri doğru oynamakta, saat yönünün tersine doğru çevirdiğinde ise film tekrar bașa sarmaktadır. Ayrıca filmin yürütme hızı uygulanan kuvvete göre değiştirilebilmektedir [50]. 
M.F. Akbaş vd. / Arttırılmış Gerçeklikte İşaretçi Tabanlı Takip Sistemleri Üzerine Bir Literatür Çalışması ve Tasarlanan Çok Katmanlı İșaretçi Modeli

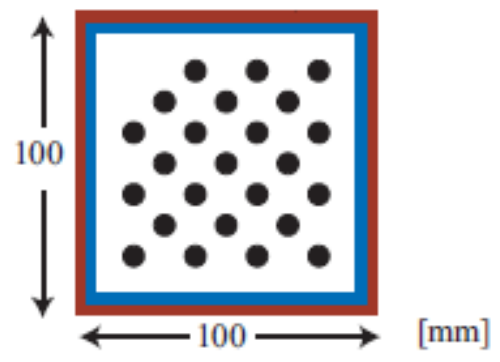

Şekil 13. ARForce kare işaretçisi [50]

İşaretçilerin kullanıldı̆̆ $\quad$ takip yöntemlerinde işaretçi mutlaka görünür olmalı ve uygun bir ölçekten gözlemlenebilir olmalıdır. $\mathrm{Bu}$ durum kamera hareketini kısıtlayan bir problem olarak karşımıza çıkmaktadır. Bu problemin önüne geçmek için yapılan bir çalışmada kare işaretçilerin kullanıldığı iç içe ișaretçi modeli önerilmektedir. En üstte bulunan işaretçi, bir altında bulunan kendinden daha küçük dört işaretçiden oluşmaktadır. $\mathrm{Bu}$ dört işaretçinin her biri de yine kendinden daha küçük dört işaretçiden oluşmaktadır (Şekil 14). Çoklu işaretçi kullanma fikri yerine iç içe işaretçilerin kullanımı ile daha geniş bir bakış açısı sağlanmaktadır. Böylece kamera hareketinin kısıtlayıcılığının önüne geçilmektedir. Ayrıca, görüntülerin farklı uzaklıklardan daha doğru ve sağlam bir şekilde geometrik olarak çakıştırılması sağlanmaktadır [51]. İç içe işaretçi modeli, bu çalışmada anlatılan çok katmanlı işaretçi modeline benzemekte olup, 2,1 cm ile $80 \mathrm{~cm}$ arasinda görüntüleme yapabilmektedir. Tasarlamış olduğumuz çok katmanlı işaretçi modeli ise daha uzak mesafelerden de görüntüleme yapabilmeye olanak sağlamaktadır.

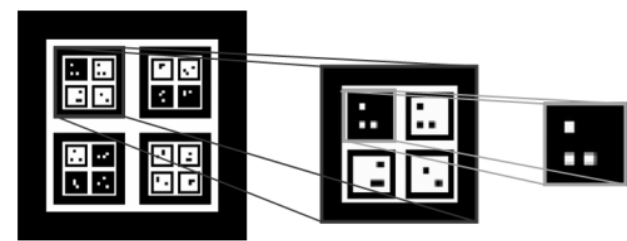

Şekil 14. İç içe işaretçi [51]
Kamera hareketini kısıtlayan bu problemin önüne geçmek için yapılan bir diğer çalıșmada ise fraktal ișaretçi alanları (Sekil 15) kullanımı önerilmektedir. Fraktal işaretçi alanı birbirinden ayrı işaretçilerden meydana gelmekte ve yapısı QR-kod veya data matrisi gibi olan matris kodlarına benzemektedir. Fraktal işaretçi alanı kullanımı arttırılmış gerçeklik sistemlerinde önemli ölçüde kamera hareketinin serbestliğini sağlamaktadır [52]

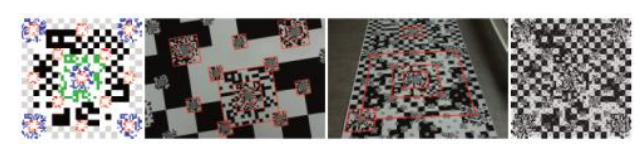

Şekil 15. Fraktal işaretçi alanları [52]

Bir başka çalışmada, işaretçilerin tespit edilebilmesi için topolojik tabanlı bir takip yöntemi önerilmektedir. Kameradan alınan film kareleri ve işaretçiler bir eşik değeri kullanılarak siyah ve beyaz renklerden oluşan ikili görüntü haline çevrilmekte ve karşıllk gelen topolojik ağaçlar çıkarılmaktadır (Şekil 16). Önerilen ișaretçi sisteminin yapılan testlerde ARToolKit'den daha başarı olduğu belirtilmektedir. Ayrıca, işaretçi parçalarının birbirinden bağımsız olarak ortama yerleştirilebilmesini ve işaretçi topolojisi bozulmadığı müddetçe işaretçinin kapatılabilmesini sağlamaktadır [33].

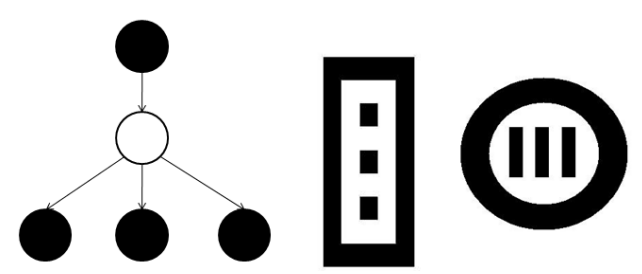

Şekil 16. Topoloji ağacı ve karșıllk gelen iki farklı geometrik şekil [33]

\section{2. İşaretçisiz tabanlı takip}

Arttırılmış gerçeklik etkisi oluşturmak için işaretçisiz tabanlı takip (markerlessbased tracking) yöntemi kullanmak da mümkündür. Ișaretçisiz takip 
M.F. Akbaş vd. / Arttırılmış Gerçeklikte İşaretçi Tabanlı Takip Sistemleri Üzerine Bir Literatür Çalışması ve Tasarlanan Çok Katmanlı İşaretçi Modeli

yönteminde, gerçek dünya ortamında önceden eğitilmiş herhangi bir işaretçi bulunmamaktadır. Bunun yerine, gerçekliğin zenginleştirilmesi için pencere köşesi, kitap kapağı, uydu görüntüsü gibi gerçek dünyada bulunan doğal hedefler kullanılmaktadır. Bu yüzden literatürde doğal özelliklerin referans alındığı takip (natural featuresbased tracking) yöntemi olarak da bilinmektedir. Doğal özellikler kullanılarak yapılan takip yöntemi karmaşık bir yapıya sahiptir ve yüksek hesaplama gücüne gereksinim duyulmaktadır. Özellikle sınırlı hesaplama kaynaklarının kullanıldığı mobil cihazlar üzerindeki arttırılmıș gerçeklik uygulamalarında kullanımı çok kolay değildir. Mobil cihazlar, arttırılmış gerçeklik için ilgi çekici bir platform olsa da düşük işlemci gücüne, yavaş belleğe ve çok küçük ön belleğe sahip gömülü sistemlerdir. Mobil cihazların sahip olduğu bu kısıtlar, doğal özelliklerin kullanıldığı takip yöntemi için engel teşkil etmektedir. Doğal özelliklerin referans alındığı takip yöntemi için çeşitli yaklaşımlar önerilmektedir. $\mathrm{Bu}$ yaklaşımlar, mobil cihazlar üzerinde gerçek zamanlı olarak düzlemsel hedeflerden duruş tahminlemesine izin vermektedir. SIFT ve Ferns adı verilen iki algoritmik teknik bulunmaktadır. Karmaşık ve işlemsel açıdan pahalı olmasına rağmen güçlü bir özellik tanımlayıcısı olan SIFT, görüntünün yerini tespit etmek için anahtar noktaların yerini belirleme (keypoint localization), özellik tanımı (feature description) ve özellik eşleme (feature matching) adımlarından oluşmaktadır. Bayes kuralını kullanan ve sınıflandırma yapan Ferns hızlı olmasına karşılık yüksek miktarda belleğe gereksinim duymaktadır. Performans açısından karşılaştırıldığında SIFT algoritması Ferns algoritmasına göre daha kararlıdır. Fakat işlemci gücü ve bellek miktarı arttırıldığında Ferns daha üstün performans gösterebilmektedir [53].
Mobil cihazlar üzerinde doğal özellikler kullanılarak yapılan takip için SIFT ve Ferns teknikleri üzerinde birtakım değişiklikler yapılmış ve mobil cihazlar için daha uygun hale getirilmiştir. Ayrıca şablon tabanlı takip yöntemi kullanılarak SIFT ve Ferns tekniklerinin performansı daha iyi hale getirilmiștir [54].

İşaretçisiz tabanlı yöntem kullanılarak geliştirilen ve PDA üzerinde çalışan bir başka mobil arttırılmış gerçeklik sisteminde nesnenin tanımlanması ve yerinin belirlenmesi için kamera görüntülerinden 2-boyutlu özellikler çıkartılmakta ve veritabanında bulunan 3-boyutlu modeller ile karșilaștırma işlemi yapılmaktadır. Sistem, 2-boyutlu graf eșleme, 3-boyutlu hipotez üretimi (hypothesis generation) ve doğrulama (verification) adımlarından oluşmaktadır. Algoritmalar, PC tabanlı bir sunucu üzerinde çalıştırılmakta olup PDA ile sunucu kablosuz ağ bağlantısı ile iletişim kurmaktadır [55].

\section{Tasarlanan Çok Katmanlı İşaretçi Modeli}

$\mathrm{Bu}$ bölümde, tasarlanan çok katmanlı işaretçi modeli tanıtılmakta ve bu işaretçi modelinin sunduğu katkılar anlatılmaktadır. Ayrıca, her bir katmanda bulunan işaretçi için görüntülemenin yapılabildiği takip mesafeleri ölçülmekte ve gözlemlenen değerlere yer verilmektedir. Çalışmada, açık kaynak kodlu ve $\mathrm{C}, \mathrm{C}++$ tabanlı bir arttırılmış gerçeklik kütüphanesi olan ARToolKit kullanılmaktadır. ARToolKit, masaüstü ve mobil arttırılmış gerçeklik uygulamalarında en yaygın kullanılan kütüphane olması nedeniyle tercih edilmiştir. 3-boyutlu grafiklerin programlanabilmesi için OpenGL [56] ve donanım olarak Pentium i7 işlemciye ve 8 GB belleğe sahip bir PC, 1,5 GB belleğe sahip GeForce GTX 480 ekran kartı ve 1280x768 çözünürlüğüne sahip Microsoft HD web kamerası kullanılmaktadır. 
Tüm işaretçi tabanlı takip sistemleri, benzersiz desenlerden ve bilgisayarlı görü algoritmalarından oluşmaktadır. $\mathrm{Bu}$ sistemlerde, görüntü işleme ise benzersiz özelliklerin tespit edilmesi (unique feature detection) ve doğrulama/ tanımlama (verification/identification) adımlarından oluşmaktadır. ARToolKit, arttırılmış gerçeklik uygulamalarında kullanılan ilk işaretçi tabanlı takip sistemidir. Sonrasında ise ARToolKit Plus ve ARTag gibi işaretçi tabanlı takip sistemleri geliștirilmiștir. ARToolKit Plus, ARToolKit'in optimize edilmiş versiyonudur. ARToolKit Plus ile ARToolKit kütüphanesinde benzersiz özelliklerin tespit edilmesi adımı aynı olup ikili eșiklenmiș görüntü kullanılmaktadır. ARToolKit Plus, doğrulama/tanımlama adımında ARToolKit'den farklılık göstermektedir. $\mathrm{Bu}$ adımda, ARToolKit'de korelasyon kullanılırken ARToolKit Plus'da dijital yöntemler kullanılmaktadır. ARTag'de ise benzersiz özelliklerin tespit edilmesi adımında kenar tabanlı tespit yaklaşımı ve doğrulama/tanımlama adımında dijital kodlama yöntemi kullanılmaktadır. ARToolKit işaretçileri kullanıcı tarafından tanımlanabilen desenler olup ARToolKit Plus ve ARTag işaretçileri önceden tasarlanmıș desenlerden oluşmaktadır. ARTag ile ARToolKit Plus işaretçileri görünüş olarak birbirine çok benzemektedir. Buna karşın, ARTag'in sahip olduğu kenar tabanlı tespit yaklaşımı ve hata düzeltme özelliği ARToolKit Plus'da bulunmamaktadır. ARTag, ARToolKit ve ARToolKit Plus'dan daha düşük yanlış negatif oranına sahiptir [57].

Arttırılmış gerçeklik uygulamalarında karşılaşılan en önemli zorluklardan biri kullanıcının bakış açısının takip edilmesi problemidir. Uygulama, kullanıcının gerçek dünyada nereden bakıyor olduğunu bilmek zorundadır. Bu yüzden kullanıcının baktığı noktanın hassas bir şekilde ve gerçek zamanlı olarak hesaplanması gerekmektedir. $\mathrm{Bu}$ hesaplamanın doğru olarak yapılması sanal içeriklerin gerçek dünyadaki nesnelerle birlikte daha düzgün görüntülenmesini sağlayacaktır. ARToolKit, bakış açısının takip edilmesi problemini bilgisayarlı görü algoritmaları ile çözmektedir. ARToolKit, gerçek kameranın konumunu ve yönünü, ortamda bulunan işaretçilere göre gerçek zamanlı hesaplamaktadır. Ayrıca ARToolKit'in sahip olduğu hızlı ve hassas takip mekanizması birçok yeni arttırılmış gerçeklik uygulamasının kolay bir şekilde geliştirilmesini sağlamaktadır. Takip mekanizması, siyah sınırlara sahip kare ișaretçileri kullanmaktadır. Herhangi bir kare șeklindeki ișaretçiyi kullanabilme yeteneği, kameranın kolay bir şekilde yapılandırılabilmesi, gerçek zamanlı arttırılmış gerçeklik uygulamaları için hızlı oluşu, açık kaynak kodlu olması ve Windows, Linux, MacOS X gibi çeşitli platformlarda çalışabilmesi, ARToolKit'i en popüler arttırılmış gerçeklik uygulamaları geliștirme kütüphanesi olarak öne çıkartan özelliklerdir [16]. Bu yüzden, ARToolKit kütüphanesi birçok arttırılmış gerçeklik projesinde yaygın olarak kullanılmaktadır.

ARToolKit kullanılarak geliştirilen uygulamalar iki bölümden oluşmaktadır. Bunlardan biri, uygulamanın kodlanması diğeri ise uygulamada kullanılacak olan işaretçilerin görüntü işleme teknikleri ile eğitilmesi sürecidir. Gerçek dünyadaki canlı görüntüler ile sanal görüntüleri üst üste getirmeye olanak sağlayan ARToolKit uygulamalarında işaretçi olarak kullanılan siyah kareler önemli bir rol oynamaktadır. Şekil 17 'de bu çalışma kapsamında kullanılan ARToolKit kütüphanesinin çalışma prensibi gösterilmektedir. Öncelikle, kamera gerçek dünya görüntüsünü yakalar ve bilgisayara gönderir. Her bir film karesinde kare şekiller aranır. Önceden eğitilmiș desenler ile kare șekil içindeki desen eşleşiyorsa, kare şekil işaretçi 
M.F. Akbaş vd. / Arttırılmış Gerçeklikte İşaretçi Tabanlı Takip Sistemleri Üzerine Bir Literatür Çalışmasıı ve Tasarlanan Çok Katmanlı İșaretçi Modeli

olarak tanımlanır. İşaretçi tespit edildikten sonra kameranın konum bilgisi işaretçiye göre hesaplanır. Konum bilgisi hesaplandıktan sonra ise bilgisayar ortamında üretilmiş olan modeller işaretçinin üzerine düşürülür. Böylece dijital içeriğin gerçek dünya üzerinde görünmesi sağlanmıș olur [58].

Görü tabanlı arttırılmış gerçeklik sistemlerinin bir takım zorlukları ve kısıtlamaları bulunmaktadır. İşaretçilerin sürekli görüş alanında bulunmasının gerekmesi, mesafe sorunu, desenin karmaşıklığı, ışıklandırma gibi unsurlar görüntülemeyi etkileyen faktörlerdir. Dijital içerikler, ancak ișaretçilerin görünür olduğu durumlarda gerçek dünya üzerinde görüntülenebilmektedir. Aksi halde görüntüleme gerçekleşmemektedir. Ayrıca kullanıcının, desenin bir bölümünü elleriyle kapatması dijital içeriklerin kaybolmasına neden olmaktadır. Arttırılmış gerçeklik uygulaması geliștirirken yaşanan en büyük problemlerden biri de mesafe sorunudur. Kullanılan mobil cihazın kamerası desenden uzaklaştırıldığında sanal nesneler kaybolmaktadır. Desenlerin daha büyük boyutlarda olması daha uzak mesafelerden tanımlanabilmelerini sağlamaktadır. Bunun yanı sıra desenin karmaşıklığı, takip mesafesini etkileyen bir diğer unsurdur. Desenin basit olması bu açıdan önemlidir. Geniş, siyah ve beyaz bölgelerden oluşan desenler performans açısından daha etkilidir. Takip mesafesi üzerinde, ișaretçinin yönü de etkilidir. İșaretçiler daha eğik ve yatay oldukça desenlerin görünebilirliği azalmakta ve tanımlanabilmeleri daha zor bir hale gelmektedir. Işıklandırma koşulları da işaretçilerin takibinde önemli bir faktördür. Fazla ışıklar, işaretçinin bulunduğu kâğıt üzerinde yansımalara ve parlayan ışılklara sebep olarak işaretçinin tespit edilebilmesini zorlaştırmaktadır [58]. Tablo 1'de farklı boyutlardaki ARToolKit işaretçileri için görüntülemenin yapılabildiği takip mesafeleri gösterilmektedir.

Tablo 1. ARToolKit işaretçilerinin boyutu ve takip mesafeleri [58]

\begin{tabular}{|c|c|}
\hline Desen Boyutu $(\mathrm{cm})$ & Takip Mesafesi $(\mathrm{cm})$ \\
\hline $6.98(2.75 \mathrm{inç})$ & $40.64(16$ inç) \\
\hline $8.89(3.50 \mathrm{inç})$ & $63.5 \quad(25 \mathrm{inç})$ \\
\hline $10.79(4.25 \mathrm{inç})$ & $86.36(34 \mathrm{inç})$ \\
\hline $18.71(7.37 \mathrm{inç})$ & $127 \quad(50 \mathrm{inç})$ \\
\hline
\end{tabular}

ARToolKit uygulamalarında kullanıcı ile işaretçi arasındaki uzaklık oldukça kısa olup genellikle 1 m'nin altındadır. İşaretçiden uzaklaşıldıkça ise hatalar olușmaktadır. Malbezin ve arkadaşları, ARToolKit kütüphanesinde bulunan takip mekanizmasının doğruluğunu ölçmek için bazı deneysel çalışmalar yapmışlardır. ARToolKit'in takip yeteneği $1 \mathrm{~m}$ ile $3 \mathrm{~m}$ aralığında ve farklı açlarda test edilmiştir. Deney için $20 \mathrm{~cm}$ x 20 cm'lik asimetrik bir desen kullanılmıştır. Kamera, 3 m'den sonra işaretçiyi tespit edememiştir ve bu yüzden üst limit $2,5 \mathrm{~m}$ olarak alınmıştır. Ölçüm sonuçlarında işaretçiden uzaklaşıldıkça konumlandırmadaki hatanın arttığı ve işaretçinin yörüngesi etrafında gezinildiğinde hatanın $\mathrm{X}$ ve $\mathrm{Y}$ eksenleri yönünde değişkenlik gösterdiği belirtilmektedir. [59]. Tablo 2'de ölçülen hata değerleri gösterilmektedir.

Tablo 2. Dört uzaklık değeri için ölçülen maksimum hata değerleri [59]

\begin{tabular}{|c|c|c|c|c|}
\hline Uzaklık (m) & 1 & 1.5 & 2 & 2.5 \\
\hline Hata (mm) & \pm 14 & \pm 18 & \pm 22 & \pm 27 \\
\hline
\end{tabular}




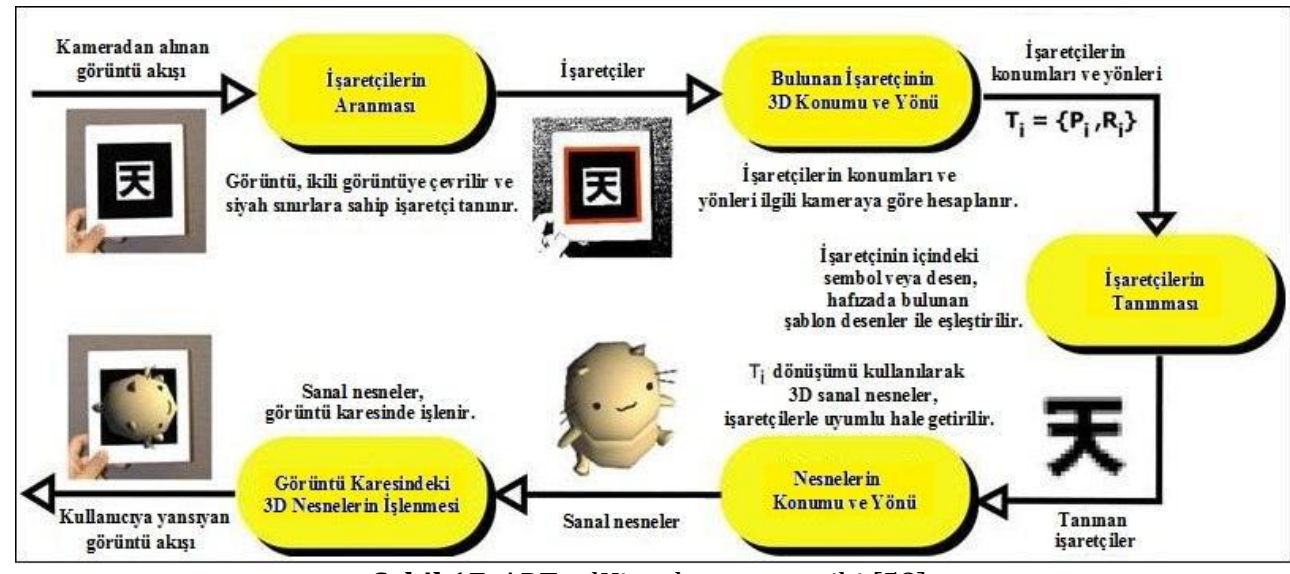

Şekil 17. ARToolKit çalışma prensibi [58]

tam olarak görememekte ve sanal

İşaretçilerin şeklinin (siyah-beyaz oranı, kenar keskinliği, bilgi karmaşıklığı), işaretçilerin yerleşimlerinin ve ortam koşullarının (yüzeyin düzgünlüğü, ışık yoğunluğu, ışık-işaretçi-kamera açısı, kameranın fiziksel hareketi), programlama parametrelerinin (çerçeve oranı, ișaretçi kesimlemesi) ve kullanılan donanımın (kamera çözünürlüğü, yazıcının kalitesi) ARToolKit işaretçilerinin tasarımını ve takibini etkileyen unsurlar olduğu belirtilmektedir. ARToolKit ișaretçileri geliştirilirken bu unsurların dikkate alınmasının işaretçilerin kalitesini etkileyeceği ifade edilmektedir [60].

$\mathrm{Bu}$ çalışmada, ARToolKit kütüphanesi kullanılarak tasarlanan çok katmanlı işaretçi modeli tanıtılmaktadır. Birden fazla katmana sahip bir mimarinin tasarlanmasındaki amaç, sanal içeriklerin detaylarını yakından izleyebilme ve belli bir mesafeden sonra görüntünün kaybolmamasının sağlanmasıdır. Sadece küçük boyutlarda bir işaretçi kullanıldığında kamera belli bir uzaklıktan sonra işaretçiyi algllayamamakta ve görüntü kaybolmaktadır. Tersine sadece büyük boyutlarda bir ișaretçi kullanıldığında ise kamera ile işaretçiye yaklaşıp sanal içeriğin detayları görmek istendiğinde işaretçinin siyah sınırlarına girildiğinden dolayı kamera yakın mesafeden işaretçiyi içeriğin detaylarını görmek mümkün olmamaktadır. ARToolKit kütüphanesine eklediğimiz çok katmanlı işaretçi modeli ile bu problemin çözümüne katkı sağlanmaktadır [1].

Kare ișaretçiler, arttırılmıș gerçeklik uygulamalarında yaygın olarak kullanılmaktadır. Çalışmada bir (Şekil 18) ve iki (Şekil 19) katmandan oluşan kare işaretçiler tasarlanmıştır. İşaretçiler, dışı siyah renkli kalın sınırlara sahip ve içinde simetrik olmayan desenlerin bulunduğu beyaz karesel bölgeden oluşmaktadır. İşaretçinin tasarımında görüntülemenin performansı açısından siyah ve beyaz renkler kullanılmaktadır. Ayrıca desenin karmaşıklığının az olmasına yani çok fazla ayrıntı içermemesine de dikkat edilmiştir. Görüntü akışında kare şekillerin aranması sonucu ișaretçiler tespit edilmektedir. Tespit edilen kare işaretçilerin içindeki desenlerin tanımlanması ise şablon eşleme (template matching) yoluyla gerçekleşmektedir. Sistemde önceden eğitilmiş mevcut desen ile görüntü akışındaki kare şeklin içindeki desen eşleştirilmektedir. Önceden eğitilmiş olan bu desenler, çalışma zamanında yüklenmektedir. Şekil 18'de tasarladığımız 'patt.UBE' adlı tek katmanlı işaretçi gösterilmektedir. 
M.F. Akbaş vd. / Arttırılmış Gerçeklikte İşaretçi Tabanlı Takip Sistemleri Üzerine Bir Literatür Çalışması ve Tasarlanan Cok Katmanlı İșaretçi Modeli

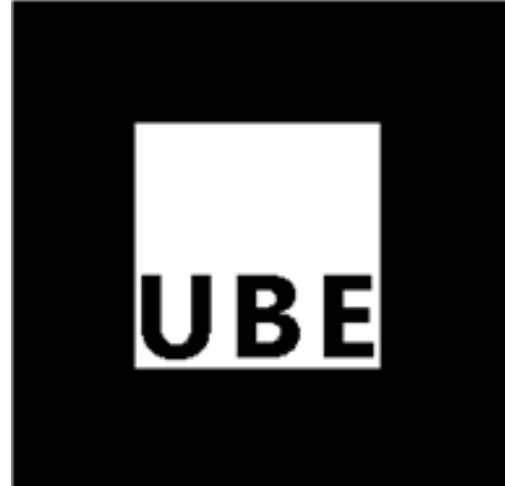

Şekil 18. Bir katmanlı kare işaretçi [1]

Şekil 19'da ise tasarladığımız 'patt.multi' adlı iki katmanlı işaretçi gösterilmektedir. Çok katmanlı bu mimaride merkezleri ortak iç içe iki işaretçi ve bu işaretçilerin içinde farklı desenler bulunmaktadır. İç katmandaki (birinci katman) desen sadece 'UBE' kelimesinden olușmakta diș katmandaki (ikinci katman) desen ise alt alta yazlan 'Uluslararası Bilgisayar Enstitüsü' kelimelerinden ve iç katmandaki işaretçiden oluşmaktadır. Yani iç katmandaki işaretçi, dış katmandaki işaretçinin deseni olacak şekilde tasarlanmıştır.

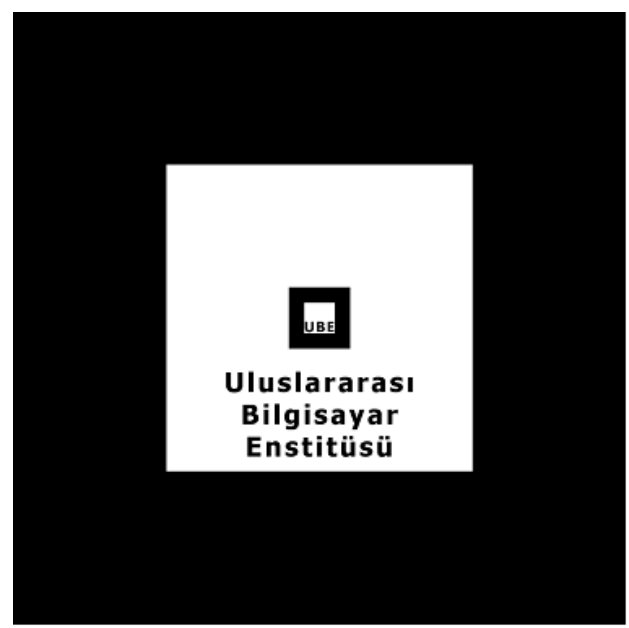

Şekil 19. İki katmanlı kare işaretçi [1]

ARToolKit'in görüntü işleme kütüphanesi kullanılarak eğitilen bu işaretçi modeli, geliştirilen arttırılmış gerçeklik uygulamasında kullanılmaktadır. Kamera, iç katmandaki işaretçiyi yakaladığında Uluslararası Bilgisayar Enstitüsü binasının 3-boyutlu modeli iç katmandaki işaretçi üzerine düşürülmektedir. Kamera ile iç katmanda bulunan işaretçiye yaklaşıldıkça görüntülenen 3-boyutlu modele de yaklaşılmaktadır. Böylece modelin detaylarını yakından görmek ve etrafında dolaşmak mümkün olmaktadır. İç katmandaki işaretçinin büyüklüğünü, dış katmandaki işaretçinin büyüklügünün onda biri oranında küçültülmüş şekilde tasarlamamı modelin detaylarını görmede önemli bir rol oynamaktadır. Kamera, iç katmandaki işaretçiyi kaybettiğinde ise görüntü kaybının yaşanmaması için dış katmandaki işaretçi devreye girmektedir. Dış katmandaki işaretçi yakalandığında model belli bir uzaklıktan dış katmanda bulunan işaretçi üzerine düşürülmektedir. Böylece, iç katmandaki işaretçiden uzaklaşıldığında oluşan görüntü kaybının önüne geçilmekte olup modele daha uzak bir mesafeden bakıldığında modelin çevresindeki yapılar da görüntülenebilmektedir [1].

İlk olarak 'arVideoGetImage' fonksiyonu kullanılarak görüntü karesi yakalanmaktadır. Ardından 'arDetectMarker' fonksiyonu ile görüntü karesinde bulunan doğru işaretçi desenleri tespit edilmektedir. Bulunan işaretçilerin sayısı 'marker_num' adlı değişkende tutulmaktadır. 'marker_info' adlı değişkende ise her bir işaretçi için koordinat bilgisini, tanıma güvenilirlik değerlerini (recognition confidence values) ve işaretçi id numarasını içeren işaretçi yapılarının bir listesi tutulmaktadır. Tespit edilen işaretçilerin tanıma güvenilirlik değerleri, en yüksek tanıma güvenilirlik değerleri kullanılarak doğru işaretçi id numarası ile ilişkilendirilmek üzere karşılaștırılmaktadır. Sonrasında 'arGetTransMat' fonksiyonu kullanılarak 
M.F. Akbaş vd. / Arttırılmış Gerçeklikte İşaretçi Tabanlı Takip Sistemleri Üzerine Bir Literatür Çalışması ve Tasarlanan Çok Katmanlı İşaretçi Modeli

işaretçi ve kamera arasındaki dönüşüm bulunmaktadır. İlgili işaretçiye göre kameranın konum ve yön bilgisi ise $3 \times 4$ 'lük 'patt_trans' adlı matriste tutulmaktadır. Son olarak tamsayı tipinde bir parametre alan 'draw' fonksiyonu çağrılarak Uluslararası Bilgisayar Enstitüsü binasının 3-boyutlu modeli eğitilen çok katmanlı işaretçinin ilgili katmanı üzerine çizilmektedir. Kamera, iç katmandaki işaretçiyi tespit ettiğinde 'draw' fonksiyonu parametre değeri ' 1 ' olacak ş̧ekilde çağrılmakta ve model iç katmandaki işaretçi üzerine düşürülmektedir (Şekil 20 ve Şekil 21).

$$
\mathrm{k}=-1 \text {; }
$$

for $(j=0 ; j<$ marker_num; $j++)$

\{

/* İç katmandaki desen algılandığında */

if (patt_id == marker_info[j].id)

\{

$\operatorname{iff}(k==-1) k=j$;

else iff marker_info[k].cf < marker_info[j].cf )

$\mathrm{k}=\mathrm{j}$;

/* Kamera ile işaretçi arasındaki dönüşüm

bilgisi alınır. */

arGetTransMat(\&marker_info[k],

patt_center, patt_width1, patt_trans);

/ İç katmandaki desen üzerine model

çizilir. */

draw(1); break;
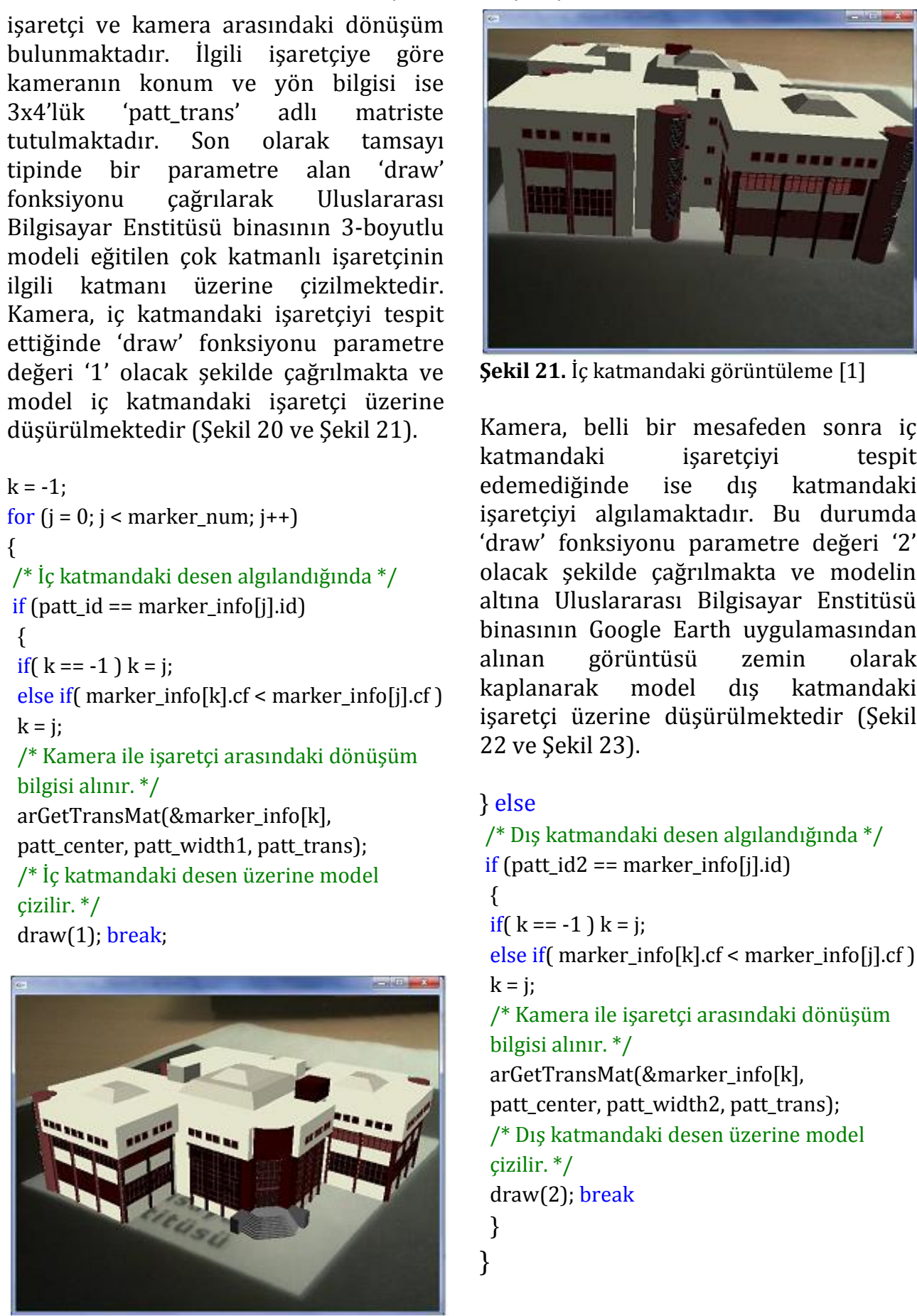

Şekil 21. İç katmandaki görüntüleme [1]

Kamera, belli bir mesafeden sonra iç katmandaki ișaretçiyi tespit edemediğinde ise dıș katmandaki işaretçiyi algılamaktadır. Bu durumda 'draw' fonksiyonu parametre değeri ' 2 ' olacak șekilde çağrılmakta ve modelin altına Uluslararası Bilgisayar Enstitüsü binasının Google Earth uygulamasindan alınan görüntüsü zemin olarak kaplanarak model diș katmandaki işaretçi üzerine düşürülmektedir (Şekil 22 ve Şekil 23).

\} else

/* Dış katmandaki desen algılandığında */

if (patt_id2 $==$ marker_info[j].id)

\{

$\operatorname{if}(k==-1) k=j$;

else if( marker_info[k].cf < marker_info[j].cf ) $\mathrm{k}=\mathrm{j}$;

/* Kamera ile işaretçi arasındaki dönüşüm

bilgisi alınır. */

arGetTransMat(\&marker_info[k], patt_center, patt_width2, patt_trans); /* Dış katmandaki desen üzerine model çizilir.*/

draw(2); break \}

Şekil 20. İç katmandaki görüntüleme [1] 
M.F. Akbaş vd. / Arttırılmış Gerçeklikte İşaretçi Tabanlı Takip Sistemleri Üzerine Bir Literatür Çalışması ve Tasarlanan Çok Katmanlı İșaretçi Modeli

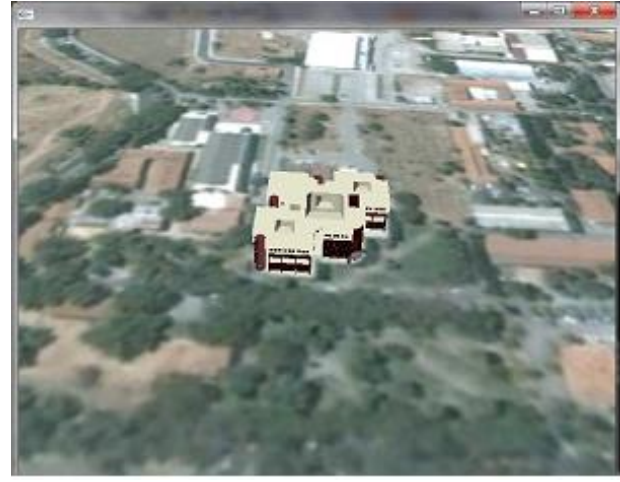

Şekil 22. Dış katmandaki görüntüleme [1]



Şekil 23. Dış katmandaki görüntüleme [1]

İç katmandaki kare işaretçinin kenar uzunluğu $2 \mathrm{~cm}$, diş katmandaki kare işaretçinin kenar uzunluğu $20 \mathrm{~cm}$ 'dir. Yani içerideki desen dışarıdaki desenin onda biri oranındadır. Yapılan ölçümlerde iç katmanda bulunan işaretçinin $5 \mathrm{~cm}$ ile $55 \mathrm{~cm}$ arasında görüntüleme yapabildiği gözlemlenmiştir. $55 \mathrm{~cm}$ uzaklıktan sonra ise dış katmana geçiş yapılmakta ve geçiş esnasında herhangi bir gecikme yaşanmamaktadır. Dış katmanda bulunan işaretçinin ise $55 \mathrm{~cm}$ ile yaklaşık 10 m'ye kadar görüntüleme yapabildiği gözlemlenmiştir. Tablo 3'de iç ve diş katmanlarda bulunan işaretçilerin kullanılabilir takip mesafeleri gösterilmektedir. Ayrıca, ARToolKit'de bulunan Şekil 8'deki Hiro ve Kanji desenlerine sahip işaretçiler de ölçümlere tabi tutulmuş ve daha basit tasarıma sahip olmaları nedeniyle 10 m'nin üstü değerler de gözlemlenmiștir.
Arttırılmış gerçeklik uygulaması geliștiricileri, tasarlamış olduğumuz bu çok katmanlı ișaretçi modelini kullanarak 5 cm'den 2-3 m'ye kadar rahatlıkla çalışma yapabilirler. Gerekirse işaretçiden 10 m'ye kadar uzaklaşabilirler.

Tablo 3. Çok katmanlı işaretçi modelinin takip mesafeleri

\begin{tabular}{|c|c|c|}
\hline $\begin{array}{c}\text { İşaretçi / } \\
\text { Takip } \\
\text { Mesafesi }\end{array}$ & $\begin{array}{c}\text { Minimum } \\
\text { Takip } \\
\text { Mesafesi } \\
\text { (cm) }\end{array}$ & $\begin{array}{c}\text { Maksimum } \\
\text { Takip } \\
\text { Mesafesi } \\
\text { (cm) }\end{array}$ \\
\hline $\begin{array}{c}\text { İç Katman } \\
\text { (1. Katman) }\end{array}$ & $5 \mathrm{~cm}$ & $55 \mathrm{~cm}$ \\
\hline $\begin{array}{c}\text { Dış Katman } \\
\text { (2.Katman) }\end{array}$ & $55 \mathrm{~cm}$ & $\sim 10 \mathrm{~m}$ \\
\hline
\end{tabular}

\section{Sonuçlar}

Arttırılmış gerçeklik kavramı özellikle son yıllarda yeni nesil mobil cihazların yaygınlaşması ve sunduğu birtakım gelişmiş özellikler sayesinde üzerinde çalışılan ve ilgi çekici bir konu haline gelmiştir. Arttırılmış gerçeklikte ana fikir, gerçekliğin arttırılması yani diğer bir deyişle gerçek dünyanın bilgisayardan gelen sayısal bilgiler ve görüntülerle zenginleștirilmesi, daha faydalı ve işlevsel bir hale getirilmesi sürecidir.

$\mathrm{Bu}$ kavram, eğitim alanında, reklam ve eğlence sektöründe, mühendislik ve mimarlık uygulamalarında bașta olmak üzere çok geniş yelpazede kendine uygulama alanı bulmaktadır. Önümüzdeki yıllarda da özellikle mobil platformlarda adından en fazla söz ettirecek teknolojiler arasinda gösterilmektedir.

Bir arttırılmış gerçeklik sisteminin temel bileșeni olan takip mekanizması gerçek dünyadaki nesneleri tespit etmekte ve bunlara ait 3-boyutlu konum ve yön bilgisini çıkartmaktadır. Literatürde, ișaretçi tabanlı veya işaretçisiz tabanlı 
gibi çeşitli takip yöntemleri önerilmiştir. Maliyetinin düşük ve kullanımının kolay olması işaretçi tabanlı sistemlerin avantajlarıdır. Bu çalışma kapsamında, arttırılmış gerçeklikte işaretçi tabanlı takip sistemleri üzerine bir literatür çalışması yapılmış ve işaretçi tabanlı takip sistemlerinde kullanılmak üzere tasarlanan çok katmanlı işaretçi modeli tanitılmıştır.

Katmanlı bir tasarıma sahip olmayan tek bir işaretçi kullanıldığında işaretçiye yakınlaştıkça, kamera işaretçinin siyah sınırlarını görememekte ve sanal içerik görüntülenememektedir. İşaretçiden uzaklaşıldığında ise işaretçi algılanamamakta ve sanal içerik yine görüntülenememektedir. Tek işaretçinin kullanımında karşılaşılan bu problemlerin çözümü için çok katmanlı bir işaretçi modeli tasarlanmıştır. Çok katmanlı işaretçi modeli, sanal içeriğin detaylarının yakından görülmesini ve işaretçiden uzaklaşıldığında oluşan görüntü kaybının önüne geçilmesini sağlamaktadır. Böylece, bilgisayar ortamında oluşturulan sanal içeriklerin, gerçek dünya üzerine düşürülmesi ve görüntülenmesi sürecinde önemli katkılar sunmaktadır. Önerilen çok katmanlı işaretçi modelinin performansı ve görüntülemenin yapılabildiği takip mesafeleri, geliştirilen arttırılmış gerçeklik uygulaması üzerinde ölçülmüştür. Yapılan ölçümlerde iç katmandaki işaretçinin $2 \mathrm{~cm}$ ile $55 \mathrm{~cm}$ arasında, dış katmandaki işaretçinin ise $55 \mathrm{~cm}$ ile yaklaşı $10 \mathrm{~m}$ arasında görüntüleme yapabildiğ $\mathrm{i}$ gözlemlenmiştir. $\mathrm{Bu}$ model, yakın mesafeden uzak mesafeye geniş bir aralıkta çalışma imkânı sağlamaktadır. Calıșma kapsamında iki katman kullanılmış olup üç veya daha fazla katman kullanmak da mümkündür.

$\mathrm{Bu}$ çalışmanın, ileriye yönelik yapılabilecek arttırılmış gerçeklik projeleri için bir referans teşkil edebileceği düşünülmektedir. Örneğin, bir semtin krokisi çıkarılarak ve her bir evin altına farklı bir işaretçi konularak, kamera ile gezildikçe binaların 3-boyutlu olarak görüntülenebilmesi sağlanabilir. Aynı şekilde, şehirlerin mimarilerinde ve yeni inşa edilen sitelerin gösteriminde kullanılabilir.

\section{Kaynakça}

[1] Akbaş, M.F. 2011. Mobil Cihazlar Üzerinde 3-Boyutlu Arttırılmış Gerçeklik Arayüz Yazılımı Geliştirme. Ege Üniversitesi, Uluslararası Bilgisayar Enstitüsü, Yüksek Lisans Tezi, 103s, İzmir.

[2] Azuma, R. 1997. A Survey of Augmented Reality, Teleoperators and Virtual Environments, Cilt. 6, No. 4, s. 355-385.

[3] Milgram, P., Kishino, F. 1994. A Taxonomy of Mixed Reality Visual Displays, IEICE Transactions on Information Systems, s. 1321-1329.

[4] Ege, B. Şubat 2014. Arttırılmış Gerçeklik, Bilim ve Teknik Dergisi.

[5] L. Frank Baum's "The Master Key" Imagines a Kind of Augmented Reality.

http://historyofinformation.com/ex panded.php?id=4698 (Erişim Tarihi: 01.04.2016).

[6] Sensorama Machine. http://www.mortonheilig.com/Inve ntorVR.html (Erişim Tarihi: 01.04.2016).

[7] Sutherland, I. 1968. A HeadMounted Three Dimensional Display, AFIPS 68: Fall Joint Computer Conference, s. 757-764.

[8] Krueger, M., Gionfriddo, T., Hinrichsen, K. 1985. Videoplace - An Artificial Reality, SIGCHI Conference on Human Factors in Computing Systems, s. 35-40.

[9] History of Virtual Reality. http://www.vrs.org.uk/virtualreality/history.html (Erişim Tarihi: 01.04.2016). 
M.F. Akbaş vd. / Arttırılmış Gerçeklikte İşaretçi Tabanlı Takip Sistemleri Üzerine Bir Literatür Çalışması ve Tasarlanan Çok Katmanlı İşaretçi Modeli

[10] Caudell, T.P., Mizell, D.W. 1992. Augmented Reality: An Application of Heads-Up Display Technology to Manual Manufacturing Processes, Twenty-Fifth Hawaii International Conference on System Sciences, Cilt. 2, s. 659-669.

[11] Rosenberg, L.B. 1993. Virtual Fixtures: Perceptual Tools for Telerobotic Manipulation, IEEE Virtual Reality Annual International Symposium, s. 76-82.

[12] Feiner, S., MacIntyre, B., Seligmann, D. 1993. Knowledge-Based Augmented Reality, Communications of the ACM, Cilt. 36, No. 7, s. 53-62.

[13] Barrilleaux, J. Experiences and Observations in Applying Augmented Reality to Live Training http://jmbaai.com/vwsim99/vwsi m99.html (Erişim Tarihi: 01.04.2016).

[14] Sung, D. The History of Augmented Reality. $\quad$ http://www.pocketlint.com/news/108888-the-historyof-augmented-reality (Erişim Tarihi: 01.04.2016).

[15] Raskar, R., Welch, G., Fuchs, H. 1998. Spatially Augmented Reality, First IEEE International Workshop on Augmented Reality (IWAR 98), s. 11-20.

[16] ARToolKit. http://www.hitl.washington.edu/ar toolkit (Erişim Tarihi: 01.04.2016).

[17] Thomas, B., Close, B., Donoghue, J., Squires, J., De Bondi, P., Morris, M., Piekarski, W. 2000. ARQuake: An Outdoor/Indoor Augmented Reality First Person Application, Fourth International Symposium on Wearable Computers, s. 139-146.

[18] Wikitude.

http://www.wikitude.com/product s/wikitude-sdk (Erişim Tarihi: 01.04.2016).
[19] Wikitude and The Augmented Reality Hype Cycle. http://www.augmentedplanet.com/ 2009/04/wikitude-and-theaugmented-reality-hype-cycle (Erişim Tarihi: 01.04.2016).

[20] Readers Choice Awards 2012 Results.

http://www.augmentedplanet.com/ 2012/10/readers-choice-awards2012-results (Erişim Tarihi: 01.04.2016).

[21] Layar. https://www.layar.com/solutions/ \#sdk (Erişim Tarihi: 01.04.2016).

[22] What is FLARToolKit. http://www.libspark.org/wiki/saqo osha/FLARToolKit/en (Erişim Tarihi: 01.04.2016).

[23] Vuzix. https://www.vuzix.com (Erişim Tarihi: 01.04.2016).

[24] Meta. https://www.getameta.com (Erişim Tarihi: 01.04.2016).

[25] Google Glass. https://www.google.com/glass/star $\underline{\mathrm{t}}$ (Erişim Tarihi: 01.04.2016).

[26] Microsoft HoloLens. https://www.microsoft.com/micros oft-hololens/en-us (Erişim Tarihi: 01.04.2016).

[27] Van Krevelen, D.W.F., Poelman, R. 2010. A Survey of Augmented Reality Technologies, Applications and Limitations, The International Journal of Virtual Reality, Cilt. 9, No. 2, s. 1-20.

[28] Nivedha, S., Hemalatha, S. 2015. A Survey on Augmented Reality, International Research Journal of Engineering and Technology (IRJET), Cilt. 2, No. 2, s. 87-96.

[29] Bimber, O., Raskar, R. 2006. Modern Approaches to Augmented Reality, ACM SIGGRAPH.

[30] Mallem, M. 2010. Augmented Reality: Issues, Trends and Challanges, 2nd International Conference on Image Processing Theory Tools and Applications (IPTA), s. 8. 
M.F. Akbaş vd. / Arttırılmış Gerçeklikte İşaretçi Tabanlı Takip Sistemleri Üzerine Bir Literatür Çalışması ve Tasarlanan Çok Katmanlı İșaretçi Modeli

[31] Alkhamisi, A.O., Monowar, M.M. 2013. Rise of Augmented Reality: Current and Future Application Areas, International Journal of Internet and Distributed Systems (IJIDS), Cilt. 1, No. 4, s. 25-34.

[32] Azuma, R., Baillot, Y., Behringer, R., Feiner, S., Julier, S., MacIntyre, B. 2001. Recent Advances in Augmented Reality, IEEE Computer Graphics and Applications, Cilt. 21, No. 6, s. 34-47.

[33] Ercan, M. 2010. A 3D Topological Tracking System for Augmented Reality. Orta Doğu Teknik Üniversitesi, Bilgisayar Mühendisliği Bölümü, Yüksek Lisans Tezi, 61s, Ankara.

[34] Azuma, R. 1993. Tracking Requirements for Augmented Reality, Communications of the ACM, Cilt. 36, No. 7, s. 50-51.

[35] Rabbi, I., Ullah, S. 2013. A Survey on Augmented Reality Challenges and Tracking, Acta Graphica, Cilt. 24, No. 1-2, s. 29-46.

[36] Cawood, S., Fiala, M. 2008. Augmented Reality: A Practical Guide, The Pragmatic Bookshelf, 1st Edition, 328s.

[37] Güngör, C., Kurt, M. 2014. Mobil Cihazlarda Görsel Arttırılmış Gerçeklik Algısının 3 Boyutlu Kırmızı-Camgöbeği Gözlükler ile Arttırılması, 22nd IEEE Signal Processing and Communications Applications Conference (SUI 2014), s. 1706-1709.

[38] Owen, C., Xiao, F., Middlin, P. 2002. What is the Best Fiducial?, The First IEEE International Workshop on Augmented Reality Toolkit, s. 98105.

[39] Fiala, M. 2010. Designing Highly Reliable Fiducial Markers, IEEE Transactions on Pattern Analysis and Machine Intelligence, Cilt. 32, No. 7, s. 1317-1324.
[40] Cho, Y., Neumann, U. 1998. Multiring Color Fiducial Systems for Scalable Fiducial Tracking Augmented Reality, IEEE Virtual Reality Annual International Symposium, s. 212.

[41] Naimark, L., Foxlin, E. 2002. Circular Data Matrix Fiducial System and Robust Image Processing for a Wearable Vision-Inertial SelfTracker, International Symposium on Mixed and Augmented Reality (ISMAR 2002), s. 27-36.

[42] Ababsa, F., Mallem, M. 2008. A Robust Circular Fiducial Detection Technique and Real-Time 3D Camera Tracking, Journal of Multimedia, Cilt. 3, No. 4, s. 34-41.

[43] ARToolKit. http://www.hitl.washington.edu/ar toolkit/documentation/devmulti.ht $\underline{\text { m }}$ (Erişim Tarihi: 01.04.2016).

[44] Kato, H., Billinghurst, M. 1999. Marker Tracking and HMD Calibration for a Video-based Augmented Reality Conferencing System, 2nd IEEE and ACM International Workshop on Augmented Reality (IWAR 99), s. 85-94.

[45] ARToolKit.

http://www.hitl.washington.edu/ar toolkit/documentation/tutorialmult i.htm (Erişim Tarihi: 01.04.2016).

[46] Rekimoto, J., Ayatsuka, Y. 2000. CyberCode: Designing Augmented Reality Environments with Visual Tags, Conference on Designing Augmented Reality Environments (DARE 2000), s. 1-10.

[47] Claus, D., Fitzgibbon, A.W. 2004. Reliable Fiducial Detection in Natural Scenes, 8th European Conference on Computer Vision (ECCV 2004), s. 469-480. 
M.F. Akbaş vd. / Arttırılmış Gerçeklikte İşaretçi Tabanlı Takip Sistemleri Üzerine Bir Literatür Çalışması ve Tasarlanan Çok Katmanlı İșaretçi Modeli

[48] Fiala, M. 2005. ARTag, A Fiducial Marker System Using Digital Techniques, IEEE Computer Society Conference on Computer Vision and Pattern Recognition (CVPR 2005), s. 590-596.

[49] Neto, V.F.d.C, Mesquita, D.B.d, Garcia, R.F, Campos, M.F.M. 2010. On the Design and Evaluation of a Precise Scalable Fiducial Marker Framework, 23rd SIBGRAPI Conference on Graphics, Patterns and Images, s. 216-223.

[50] Jo, K., Kakehi, Y., Minamizawa, K. Nii, H., Kawakami, N., Tachi, S. 2008. ARForce: A Marker-based Augmented Reality System for Force Distribution Input, International Conference on Advances in Computer Entertainment Technology (ACE 2008), s. 160-165.

[51] Tateno, K., Kitahara, I., Ohta, Y. 2007. A Nested Marker for Augmented Reality, IEEE Virtual Reality Conference (VR 07), s. 259262.

[52] Herout, A., Zacharias, M., Dubska, M. Havel, J. 2012. Fractal Marker Fields: No More Scale Limitations for Fiduciary Markers, IEEE International Symposium on Mixed and Augmented Reality (ISMAR 2012), s. 285-286.

[53] Wagner, D., Reitmayr, G., Mulloni, A., Drummond, T., Schmalstieg, D. 2008. Pose Tracking from Natural Features on Mobile Phones, 7th IEEE/ACM International Symposium on Mixed and Augmented Reality (ISMAR 2008), s. 125-134.

[54] Wagner, D., Reitmayr, G., Mulloni, A., Drummond, T., Schmalstieg, D. 2010. Real-Time Detection and Tracking for Augmented Reality on Mobile Phones, IEEE Transactions on Visualization and Computer Graphics, Cilt. 16, No. 3, s. 355-368.
[55] Beier, D., Billert, R., Bruderlin, B., Stichling, D., Kleinjohann, B. 2003. Marker-less Vision Based Tracking for Mobile Augmented Reality, The Second IEEE and ACM International Symposium on Mixed and Augmented Reality, s. 258-259.

[56] OpenGL. http://www.opengl.org (Erișim Tarihi: 01.04.2016).

[57] Fiala, M. 2005. Comparing ARTag and ARToolKit Plus Fiducial Marker Systems, IEEE International Workshop on Haptic Audio Visual Enviroments and their Applications (HAVE 2005), s. 148-153.

[58] ARToolKit. http://www.hitl.washington.edu/ar toolkit/documentation/userarwork. htm (Erişim Tarihi: 01.04.2016).

[59] Malbezin, P., Piekarski, W., Thomas, B.H. 2002. Measuring ARToolKit Accuracy in Long Distance Tracking Experiments, The First IEEE International Workshop on Augmented Reality Toolkit.

[60] Khan, D., Ullah, S., Rabbi, I. 2015. Factors Affecting the Design and Tracking of ARToolKit Markers, Computer Standards \& Interfaces, Cilt. 41, s. 56-66. 